\title{
The Effectiveness of Strategies Used by Teachers to Manage Disruptive Classroom Behaviors: A Case Study at a Religious School in Rawang, Selangor
}

\section{Wan Mazwati Wan Yusoff ${ }^{a}$, Norwati Mansor ${ }^{b}$}

\begin{abstract}
Studies have indicated that there is a positive correlation between disruptive behaviors and low academic achievement which resulted in other problems such as absenteeism, school drop-out and delinquent behaviors. Lack of knowledge and skills and failure in managing classroom disruptive behaviors have caused frustration, stress and burnout among teachers which pushed teachers to leave the profession especially novice teachers. The pervasiveness of classroom disruptive behaviors implied that strategies employed by teachers to manage disruptive behaviors are not effective. This requires immediate attention and action to find effective solutions. Therefore, this exploratory study attempts to discover the common classroom disruptive behaviors; to identify strategies used by teachers in managing misbehaviors; and to find out to what extent the strategies used by teachers were actually effective in managing classroom disruptive behaviors. This is especially critical in religious schools since the majority of teachers teaching in religious schools in the state of Selangor had no formal training in education; and they were not trained in classroom management, thus have no exposure on handling student classroom disruptive behaviors. Participants of this study were 14 teachers from a religious school in the district of Rawang, Selangor. Data collected using self-constructed instrument and semi-structured interviews were analyzed using descriptive statistics and qualitative analysis. Findings of this study revealed that majority of classroom disruptive behaviors were low-
\end{abstract}

a. Assistant Professor, Department of Fundamental and Interdisciplinary Studies, Kulliyyah of Islamic revealed Knowledge and Human Sciences. Email: wanmazwati@iium.edu.my

b. Assistant Professor, Kulliyyah of Education, International Islamic University, Malaysia 
level disruptions; nonetheless they were burdensome to teachers which led to teacher frustration. Majority of teachers used ineffective punitive measures to handle student misbehaviors. Implications from the study were discussed.

KEYWORDS: Classroom disruptive behaviors; classroom management; teacher frustration; behavior management strategies; intervention programs

\section{Introduction}

To shape good behavior is one of the primary aims of education. Recently, we have been exposed to news and videos on social media of behavior problems among students. The comments in the media made by the Malaysian public clearly showed that we are becoming anxious on the issue of deteriorating students' behavior. Majority of schools in Malaysia can be categorized into two separate public education system, one is education system provided by the federal government (public school) and the other is education system established and managed by religious departments (religious department refers to the department which manages the Islamic affair of Muslims) of all states in Malaysia. Public school allocates limited time to teach Islamic knowledge which is compulsory according to Islamic teachings. Therefore, these religious schools were established to fill the gap and because of the demand by parents who want their children to be well educated in Islamic knowledge and possess good moral character. Schools operated by religious departments lack expertise in education administration and management; lack funding and lack of trained teachers (Rosnani Hashim, 2004). Teachers who teach at these schools are well trained in Islamic knowledge but not in education. Therefore, they lack knowledge and skills in pedagogy especially in dealing with classroom disruptive behaviors.

Review of literature revealed that there is a correlation between troublesome classroom behaviors and a gamut of antisocial, aggressivedisruptive behaviors and psychiatric problems (Thomas, Bierman, Powers, and The Conduct Problems Prevention Research Group, 2011). Studies have shown that classroom disruptive behaviors have led to more serious problems than distraction and loss of valuable time during teaching and learning process. Student classroom misbehavior is linked with student disengagement which correlates with alienation by peers and truancy (Soodak, 2003; Zyngier, 2007). Students who 
misbehaved were reported to perform worse or fail academically (Caspi, Moffitt, Newman \& Silva, 1996; Morrison, Anthony, Storino \& Dillon, 2001; Marzano \& Marzano, 2003; Finn, Fish \& Scott, 2008; Freiberg, Huzinec \& Templeton, 2009; Angus, McDonald, Ormond, Rybarcyk, Taylor, \& Winterton, 2009) which escalated to other severe problems such as dropping out of school and delinquency (Loeber, Farrington, Stouthamer-Loeber, Moffitt \& Caspi, 1998; Stearns \& Glennie, 2006; Gutierrez \& Shoemaker, 2008). Furthermore, research findings have revealed that classroom behavior problem is a predictor for a myriad of social, behavioral, and psychiatric problems; such as antisocial behaviors, violence, high-risk sexual behavior, drug, alcohol, and tobacco abuse (Kellam, Brown, Poduska, Ialongo, Wang, \& Toyinbo, 2008; Kellam, Mackenzie, Poduska, Wang, Petras \& Wilcox, 20011).

From the perspectives of teachers, classroom management of disruptive behavior is one of the utmost concerns during teaching and learning process; and one of the primary contributors to teacher frustration, stress and burnout (Travers, 2001; Dorman, 2003; Evertson \& Weistein, 2006; Friedman, 2006; Smith \& Smith, 2006; Beaman, Wheldall \& Kemp, 2007; Kokkinos, 2007; Clunies-Ross, Little \& Kienhuis, 2008; Australian Education Union, 2008). Recurring lowlevel disruptive behaviors challenged teacher classroom management skills which caused anxiety among novice and pre-service teachers (Reinke, Stormont, Herman, Puri, \& Goel, 2011; Sullivan, Johnson, Owens, \& Conway, 2014). They reported that teacher education and training have not prepared them well in the skills of managing classroom misbehaviors (Barret \& Davis, 1995; Meister \& Melnick, 2003; Stoughton, 2007; Duck, 2007). A review of teacher education curriculum offered by International Islamic University Malaysia (IIUM) proved that teachers are not well prepared in classroom management. Managing classroom disruptive behaviors is only a small subtopic discussed in pedagogy course. This resulted in lack of skills in managing classroom disruptive behavior which was reported as one of the predictors of novice teachers leaving the profession (Sutton \& Wheatley, 2003; Gonzales, Brown, \& Slate, 2008). They also stated that another significant factor that influenced teachers to choose the specific behavior management techniques is teacher's assumption about human nature, specifically student natural tendency. Teacher who views student as naturally bad would choose classroom management strategies 
for the purpose of controlling student's behavior through punishment, force, and reward. Conversely, teacher who views student as innately good would guide student through discussion and dialogue to establish and encourage good behavior.

Students' classroom disruptive behaviors ranged from low-level nuisances to severe behavior problems. The pervasive classroom disruptive behaviors are mostly trivial and low-level disturbances. Examples of such troublesome behaviors are being late for class; disengaged during teaching and learning process; talking out of turn; making distracting noises; arguing with other students; easily angered by others; losing temper; moving around the classroom unnecessarily; and disobeying teacher's instructions (Bowen, Jensen, \& Clark, 2004; Wakschlag, Leventhal, Briggs-Gowen, Danis, Keenan, \& Hill, 2005). Severe behavior problems occur less frequently but difficult to handle. Instances of severe misbehaviors include stealing; fighting; bullying; and verbally abusing teachers and other students (Sullivan, Johnson, Owens, \& Conway, 2014). Concisely, disruptive behavior is defined as "an activity that causes distress for teachers, interrupts the learning process, and activity that lead teachers to make continuous comments to the student" (Arbuckle \& Little, 2004: 60) or any "activities which disrupt and impede teaching and learning processes" (Thompson, 2009: 43). Even though researches have highlighted that the most frequent classroom misbehaviors are trivial and mild, however the loss of time and the difficulty to manage the misbehaviors have led teachers to stress and burnout.

Research findings revealed several classroom management strategies and intervention programs implemented by teachers to deal with this problem. Some of the strategies used include changing the physical environment of the classroom (Guardina \& Fullerton, 2010); punitive measures such as controlling students behavior through negative and coercive interactions to ensure compliance (Patterson, Reid, \& Dishion, 1992; Slee, 1995), referrals, suspensions, calling parents (Wakschlag, et al., 2005), more strict school rules (Way, 2011), reprimands and redirections (Madsen, Becker, \& Thomas, 2001), sanctions (Kohn, 2006; Maguire, Ball, \& Braun, 2010), and disciplinary strategy through step system. This disciplinary strategy applies intensification of negative corrective measures beginning with, for instance, giving warning, in-class time out, out of class time out, redirection to a school 
leader, in-school suspension, out-of-school suspension, and the most extreme punishment is permanent exclusion from school (Raby, 2010). The assumption underpinning step system is that when bad behavior is corrected, student learning will also be enhanced (Maguire, Ball, $\&$ Braun, 2010). However, studies indicated that punitive measures and harsh punishment may create unruly, boisterous and disordered classroom environment (Madsen, Becker, \& Thomas, 2001); cause disobedience and rebelliousness among certain students (Way, 2011); reinforce student hostility and destructive behaviors (Rinke \& Herman, 2002); lead to negative outcomes including being dismissed by peers, academic failure, and further deterioration of antisocial behavior (Patterson, Reid, \& Dishion, 1992); and contribute to defiance and detachment, common misbehavior, and school violence (Angus et al., 2009).

Since the aim of Islamic education is to develop excellent moral character epitomized by the moral character of Prophet Muhammad, the detrimental effects of unresolved classroom disruptive behaviors would impede the achievement of the aim of Islamic education. AlAttas explains that Islamic education is to produce a well-balanced personality which resembles the personality of Prophet Muhammad (1980). Therefore, this study aims to explore the strategies used by teachers in managing classroom disruptive behaviors and to discover the extent to which the strategies used were effective in dealing with disruptive behaviors. This is to bring into consciousness the damaging effects caused by problematic classroom behaviors that necessitate urgent actions. This study also provides much needed evidence to support educator and practitioner's proposal for implementation of teacher professional development and intervention programs in schools. Specifically, this study provides understanding of the consequences of unresolved classroom troublesome behaviors to students as well as teachers; and to highlight the prevalence of common disruptive behaviors in classroom is the result of ineffective strategies used by teachers. Further, this study contributes significantly to the existing literature on classroom management specifically in dealing with student disruptive behaviors in classroom since literature on this issue is really lacking in Malaysia. Search for studies done in Malaysian context especially in religious schools proves futile. Many studies in Malaysia 
were focused on disciplinary problems but not specifically on disruptive behaviors in classroom during teaching and learning sessions.

\section{Methods}

This study attempted to discover the prevalence of classroom disruptive behaviors in one primary level religious school operated by Jabatan Agama Islam Selangor (Selangor Religious Department) in district of Rawang, Selangor. This case study employed survey method to collect data regarding the common classroom disruptive behaviors committed by students during teaching and learning sessions and the strategies used by teachers in dealing with those disruptive behaviors. From the review of literature (Sullivan, Johnson, Owens \& Conway 2014; Sun \& Shek, 12; Thomas, Bierman, Powers, \& The Conduct Problems Prevention Research Group, 2011), we constructed an instrument which consists of two parts. Part A listed 32 disruptive behaviors frequently committed by students and one question asking participants to list other disruptive behaviors which occurred in their classrooms. Part B listed 14 classroom management strategies reported in literature (Patterson, Reid, \& Dishion 1992; Wakschlag, et al., 2005; Raby, 2010; Way, 2011); one question whether they have employed any intervention program; and one open ended question asking participants to describe other strategies that they may have used in dealing with classroom disruptive behaviors. Semistructured interviews were conducted to get further understanding on the effects of classroom disruptive behaviors to teachers. The collected data were analyzed using descriptive statistics and qualitative analysis. Participants in this study were 14 teachers selected from a population of 30 teachers who taught primary one to primary five students in a religious school in Rawang, Selangor. The findings of this study may not be generalized to other religious schools operated either by Jabatan Agama Islam Selangor or by any other religious department in Malaysia.

\section{Findings and Discussion}

Even though teachers were given a list of 32 common classroom misbehaviors, however, teachers encountered with 24 problem behaviors. Teachers only indicated disruptive behaviours listed in the check-list given, however, no teacher specified any other classroom disruptive behaviours particular for their students. Table 1 shows the most frequent classroom disruptive behaviors committed by students. The recurring misbehaviors were trivial or low-level disturbances. The 
most common disruptive behaviors were disturbing friends, taking friends' things without permission, making disturbing noises, talking out of turn, continuously calling for teacher, looking out the window while teachers were teaching, walking to friends' desks, task disengagement, not paying attention to teachers, and mocking their friends. Only two teachers reported that their students had committed serious misbehavior such bullying, vandalism, and rebellious against teachers; however these problem behaviors occurred infrequently. Nonetheless, 10 teachers reported that their students were involved in fighting at least once or twice in a week. These findings were consistent with studies conducted by Bowen, Jensen, and Clark (2004); Wakschlag, et al. (2005); and Sullivan, Johnson, Owens and Conway (2014). The survey conducted by Sullivan and his team which was responded by 1380 teachers from South Australia revealed that teachers had to face with low-level disruptive behaviors almost on daily basis; and the most common classroom disruptive behaviors were talking out of turn, avoiding doing schoolwork and disengaging from classroom activities. Similar findings were also reported by Sun and Shek (2012). They explore teachers' perceptions on student problem behaviors in the classroom in Hong Kong schools. Their study shows that the most frequent misbehaviors encountered by teachers in classroom were disengagement from classroom activities, talking out of turn, and verbal aggression (teasing classmates, quarreling and using foul language). This study revealed that common low-level disruptive behaviors occurred not only in this specific religious school but also in Hong Kong and Australia.

Table 1: Classroom disruptive behaviors

\begin{tabular}{|c|c|c|c|c|c|}
\hline \multirow[b]{2}{*}{ Disruptive Behaviors } & \multicolumn{5}{|c|}{ Frequencies $(n=14)$} \\
\hline & $\begin{array}{l}\text { Not at } \\
\text { all }\end{array}$ & $\begin{array}{l}\text { Once } \\
\text { or } \\
\text { twice a } \\
\text { week }\end{array}$ & $\begin{array}{l}\text { Almost } \\
\text { daily }\end{array}$ & $\begin{array}{l}\text { Several } \\
\text { times } \\
\text { daily }\end{array}$ & Level \\
\hline Disturbing friends & 2 & 0 & 0 & 12 & low \\
\hline Taking friends' things & 2 & 2 & 10 & 0 & low \\
\hline Making noises & 1 & 0 & 0 & 13 & low \\
\hline Talking out of turn & 2 & 0 & 0 & 12 & low \\
\hline Singing & 10 & 0 & 4 & 0 & low \\
\hline
\end{tabular}




\begin{tabular}{|c|c|c|c|c|c|}
\hline $\begin{array}{l}\text { Continuously calling for } \\
\text { teacher }\end{array}$ & 5 & 0 & 8 & 1 & low \\
\hline Swinging on the chair & 9 & 4 & 1 & 0 & low \\
\hline Looking out the window & 2 & 0 & 9 & 3 & low \\
\hline Walking to friends' desks & 3 & 0 & 8 & 4 & low \\
\hline Task disengagement & 0 & 4 & 0 & 10 & low \\
\hline $\begin{array}{l}\text { Not paying attention to } \\
\text { teacher }\end{array}$ & 0 & 0 & 3 & 11 & low \\
\hline $\begin{array}{l}\text { Reading other books while } \\
\text { teacher was teaching }\end{array}$ & 0 & 8 & 6 & 0 & low \\
\hline $\begin{array}{l}\text { Disobeying teacher's } \\
\text { instruction }\end{array}$ & 1 & 4 & 9 & 0 & low \\
\hline Blaming other students & 9 & 0 & 5 & 0 & low \\
\hline Using rude language & 4 & 4 & 6 & 0 & low \\
\hline Making funny noises & 10 & 0 & 4 & 0 & low \\
\hline Hitting their desks & 8 & 2 & 3 & 1 & low \\
\hline Mocking friends & 2 & 2 & 10 & 0 & low \\
\hline Breaking school rules & 10 & 4 & 0 & 0 & $\begin{array}{l}\text { medi- } \\
\text { um }\end{array}$ \\
\hline Insulting friends & 12 & 2 & 0 & 0 & severe \\
\hline Fighting & 4 & 10 & 0 & 0 & severe \\
\hline Bullying & 12 & 2 & 0 & 0 & severe \\
\hline $\begin{array}{l}\text { Defying teacher's instruc- } \\
\text { tion }\end{array}$ & 12 & 2 & 0 & 0 & severe \\
\hline Vandalism & 11 & 3 & 0 & 0 & severe \\
\hline
\end{tabular}

Table 2 shows the strategies used by teachers to deal with disruptive behaviors in their classroom. Majority of teachers used punitive measures to deal with student misbehaviors. The most popular techniques were scolding; advising students not to repeat the same mistakes; arguing with students; giving punishment; and asking accusing "why" questions. Surprisingly, no teachers reported that they have stated clear classroom rules that should be followed by students together with the consequences of not following the rules. All 14 teachers admitted that their techniques failed to reduce recurrence of classroom disruptive behaviors. Since these teachers have no formal training in education, they may have applied strategies that they have 
gained through their experiences as students in school whereby teachers used the same strategies they observed their own teachers were using when they were in school. Since the strategies used on them were effective, they applied the same strategies on their students but were proven ineffective. Common practices employed by the school may also influence the strategies that teachers used to handle students' behaviors. Teachers explained that they have to deal with student misbehaviors one way or another. Even though they realized that their techniques had not reduced classroom disruptive behaviors but these were the only techniques that they knew. Furthermore, corrective measures and harsh punishment are still prevalent in religious schools throughout Malaysia.

Table 2: Strategies employed in dealing with classroom disruptive behaviors

\begin{tabular}{ll}
\hline Strategy & Frequency $(\mathrm{n}=14)$ \\
\hline Scolding & 12 \\
Criticizing & 5 \\
Advising & 14 \\
Giving sarcastic remark & 0 \\
Arguing & 14 \\
Punishing & 9 \\
Caning/beating & 1 \\
Referring to school authority & 2 \\
Asking why & 13 \\
Time-out & 1 \\
Labelling & 2 \\
Stating clear rules & 0 \\
Praising & 0 \\
\hline Discussion/dialogue & 0 \\
\hline
\end{tabular}

We have provided, in the Introduction section of this paper, many research findings that showed negative consequences of using punitive measures to control students' behavior. Not only the strategies failed to control student misbehaviors but they may reinforce the negative behaviors which could lead to negative life outcomes later in life (Bradshaw, Schaeffer, Petras, \& Ialongo, 2010). 
Teachers also informed the researchers that they have never been exposed to any intervention programs; and they were never trained in applying different strategies in dealing with student misbehaviors. They would welcome any effort by academicians and teacher educators to expose to and train them in various strategies and intervention programs to reduce classroom disruptive behaviors. Teachers also conveyed that student misbehavior, even though trivial, made them to lose their patience and to feel tired and frustrated.

\section{Implications}

Teachers, with or without classroom management skills, must deal with troublesome behaviors in their classrooms. Effective behavior management strategies lessen classroom misbehaviors (Hawkins, Catalano, Kosterman, Abbott, \& Hill, 1999); improve academic achievement and promote school readiness (Webster-Stratton \& Reid, 2004); and encourage interest in learning (Kunter, Baumert, \& Koller, 2007). There is abundance of studies that evaluated and validated various behavior management strategies that can be applied by teachers. Teacher could choose strategies that work for them and that have the following criteria: the strategies are effective, that is, they reduce and prevent the occurrence of disruptive behaviors; easy to implement, which means they would not require outside of school support, would not take much time to prepare, and can be easily accessible; and the strategies used should not take much class time and disrupt the normal classroom activities (Guardino \& Fullerton, 2010; Cholewa, SmithAdcock, \& Amatea, 2010).

Research findings revealed that appropriate behavior management techniques such as general praise; behavior specific praise; and stating clear rules met the criteria of good strategies. These simple techniques can promote student classroom engagement and may decrease disruptive classroom behaviors (Gable, Hester, Rock, \& Hughes, 2009; Henly, 2010; Kerr \& Nelson, 2010; Wheeler \& Richey, 2010; Pisacreta, Tincani, Connell, \& Axelrod, 2011; Wan Mazwati Wan Yusoff, 2012). Evidence-based behavior specific praise and stating clear rules techniques discovered and validated by Wan Mazwati Wan Yusoff are more suitable for Muslim students since these techniques were extracted from Prophet Muhammad Tradition (hadith) which is one of the primary sources of knowledge in Islam. 
Besides these behavior management strategies, studies have shown that some evidence-based intervention programs were effective in reducing classroom disruptive behaviors. These intervention programs have been evaluated by researches in a number of studies. Some examples of effective intervention programs are Good Behavior Game (Kellam et al., 2008; Kellam et al., 2011; Donaldson, Vollmer, Krous, Downs, \& Berard, 2011); Fast Track Program (CPPRG, 1999; CPPRG, 2002); Raising Healthy Children (Brown, Catalano, Fleming, Haggerty, \& Abbott, 2005; Hawkins, Kosterman, Catalano, Hill, \& Abbott, 2005); and The Incredible Years program (Webster-Stratton \& Hammond, 1997; Scott, Spender, Doolan, Jacobs, \& Aspland, 2001; WebsterStratton et al., 2008).

Besides applying behavior management techniques and intervention programs, teacher can help reduce classroom disruptive behaviors by changing the physical and emotional environment in classroom. Positive classroom emotional climate promote healthy interactions, cooperation and trust between teacher and students and students and students which may lead to lesser classroom misbehaviors (Brackett, Reyes, Rivers, Elbertson, \& Salovey, 2011). Teachers who provide structured, cooperative and supportive learning environment; encourage and reinforce good effort by students; teach students social and emotional regulation skills; use effective instructional practices; and clearly conveyed what are expected from their students were proven to experience reduction in student misbehaviors in their classroom (Walker, Ramsey, \& Gresham, 2004; Conroy, Sutherland, Vo, Carrs, \& Ogston, 2013). Another influential strategy to manage classroom misbehavior is to have good personality and high social intelligence. Teacher with high social intelligence would create supportive and positive classroom environment that enhance intrinsic motivation among students through discussion, recognition, involvement, and hinting (Yahyazadeh Jeloudar \& Aida Suraya Md Yunus, 2011).

\section{Conclusion}

The primary aim of Islamic education is to develop good moral character. Religious schools in Malaysia are entrusted with responsibility to instil Islamic knowledge and nurture good moral character. However, this noble aim would be very difficult to achieve when students misbehaviors are not treated early. From review of literature, this study has exposed 
the negative consequences of classroom disruptive behaviors, even though trivial and low-level, they may lead to an array of negative consequences to the students themselves, to the teachers, and to societies at large. Classroom disruptive behaviors were still prevalent in this religious school and punitive measures employed by teachers were ineffective. Other studies also revealed that using punitive measures to deal with classroom disruptive behaviors were ineffective and what is worse is these measures may reinforce negative behaviors. This paper also has suggested some evidence-based intervention programs which are effective to handle classroom misbehavior so that teachers and school authorities could make further investigation for implementation. In addition, we have suggested for teachers to study simple techniques that they can employ in their classroom. More importantly, teachers should have positive personality, high social intelligence and strong motivation to change for the better.

\section{Future Plan of the Research}

Findings of this research revealed that teachers at this religious school need to be trained in classroom management, specifically they need to have knowledge and skills in managing classroom misbehaviors. A plan to give these teachers 2 days training on techniques of managing classroom disruptive behaviors is in progress. This training program aims to train teachers in motivating students through behavior specific praise and correcting mistakes by stating clear rules of what students can do and cannot do. These techniques were developed from extensive analysis of authentic hadith reported by Imam Bukhari and Muslim (Wan Mazwati Wan Yusoff, 2012). For instance, techniques of correcting misbehavior by Prophet Muhammad were extracted from a thorough analysis of two authentic hadiths (hadith number 285 and 1094) reported by Muslim. When correcting mistake, we should use precise words in just one or two sentences; be general and do not specifically mention the wrongdoer's name or the word "you", this means the reminder or information is meant for all not just the wrongdoer; clearly explain the rule of what is not allowed and what is allowed. For example, to correct the mistake of a student who is talking while teacher is teaching, just say, "Students are not allowed to talk while teacher is teaching; teachers are to be respected, listened to and learned from" (Wan Mazwati Wan Yusoff \& Asyraff Hafdzan Abdullah, 2015). 
This training program will be a part of future research to validate an intervention program to manage classroom misbehaviors developed from Prophet Muhammad Tradition.

\section{Reference}

Angus, M., McDonald, T., Ormond, C., Rybarcyk, R., Taylor, A., \& Winterton, A. (2009) Trajectories of classroom behavior and academic progress: A study of student engagement with learning, Mount Lawley, Western Australia: Edith Cowen University.

Arbuckle, C. \& Little, E. (2004). 'Teachers' perceptions and management of classroom disruptive behavior during the middle years (year five to nine),' Australian Journal of Educational and Developmental Psychology, 4, 5970.

Al-Attas, Syed Muhammad Naguib. (1980). The concept of Islamic Education. Kuala Lumpur: ISTAC.

Australian Education Union (2008) New Educators Survey 2008, Result and Report.

Barret, E. R., \& Davis, S. (1995). Perceptions of beginning teachers' needs in classroom management. Teacher Education and Practice, 11, 22-27.

Beaman, R., Wheldall, K., \& Kemp, C. (2007). 'Recent research on troublesome classroom behavior: A review,' Australasian Journal of Special Education, 31(1), 45-60.

Bowen, J., Jensen, W., \& Clark, E. (2004) School based intervention for students with behavior problems, New York: Kluwer.

Brackett, M. A., Reyes, M. R. Rivers, S. E., Elbertson, N. A., \& Salovey, P. (2011). 'Classroom emotional climate, teacher affiliation and student conduct,' Journal of Classroom Interaction, 46(1), 27-36.

Bradshaw, C. P., Schaeffer, C. M., Petras, H., \& Ialongo, N. (2010). 'Predicting negative life outcomes from early aggressive-disruptive behavior trajectories: Gender differences in maladaptation across life domains,' Journal of Youth and Adolescence, 39 (8), 953-966.

Brown, E. C., Catalano, R. F., Fleming, C. B., Haggerty, K. P., \& Abbott, R. D. (2005). 'Adolescent substance use outcomes in the Raising Healthy Children Project: A two part latent growth curve analysis,' Journal of Consulting and Clinical Psychology, 73, 699-710.

Caspi, A., Moffitt, T. E., Newman, D. L., \& Silva, P. A. (1996). 'Behavioral observation at age 3 years predict adult psychiatric disorder: Longitudinal 
evidence from a birth cohort,' Archives of General Psychiatry, 53, 10331039.

Cholewa, B., Smith-Adcock, S., \& Amatea, E. (2010). 'Decreasing elementary school children's disruptive behaviors: A review of four evidence-based programs for school counselors,' Journal of School Counseling, 8(4), 1-34.

Clunies-Ross, P., Little, E., \& Kienhuis, M. (2008). 'Self-reported and actual use of proactive and reactive classroom management strategies and their relationship with teacher stress and student behavior,' Eduactional Psychology, 28, 693-710.

Conduct Problem Prevention Research Group. (1999). 'Initial impact of the Fast Track prevention trial for conduct problem: 1. The high-risk sample,' Journal Consulting and Clinical Psychology, 67, 631-647.

Conduct Problem Prevention Research Group. (2002). 'Evaluation of the first 3 years of the fast Track prevention trial with children at high risk for adolescent conduct problems,' Journal of Abnormal Child Psychology, 30, 19-35.

Conroy, M. A., Sutherland, K. S., Vo, A. K., Carrs, \& Ogston, P. L. (2013). 'Early childhood teachers' use of effective instructional practices and the collateral effects on young children behavior,' Journal of Positive Behavior Interventions, 20(10), 1-12.

Donaldson, J. M., Vollmer, T. R., Krous, T., Downs, S., \& Berard, K. P. (2011). 'An evaluation of the good behavior game in kindergarten classrooms,' $\mathrm{J}$ Appl Behav Anal., 44(3), 605-609.

Dorman, J. (2003). 'Testing a model for teacher burnout,' Australian Journal of Educational \& Developmental Psychology, 3, 35-47.

Duck, C. (2007). 'Using sounder foundation to help avoid the "why new teacher cry” phenomenon,' The Clearing House, 81(1), 29-36.

Evertson, C. M. \& Weistein, C. S. (2006) Handbook of classroom management: Research, practice, and contemporary issues, Mahwah, NJ: Lawrence Erlbaum Associates.

Finn, J.D., Fish, R. M., \& Scott, L. A. (2008). 'Educational sequelae of high school misbehavior,' The Journal of Educational Research, 101(5), 259274.

Friedman, I. A. (2006) 'Classroom management and teacher stress and burnout', In C.M. Evertson \& C. S. Weistein (Eds.), Handbook of classroom management: Research, practice, and contemporary issues, Mahwah, NJ: Lawrence Erlbaum Associates. 
Freiberg, H. S., Huzinec, C., \& Templeton, S. M. (2009). 'Classroom management-A pathway to student achievement,' Elementary School Journal, 110(1), 64-80.

Gable, R., Hester, P., Rock, M., \& Hughes, K. (2009). 'Back to basics: Rules, praise, ignoring, and reprimand revisited,' Intervention in School and Clinic, 44, 195-205.

Gonzales, L., Brown, M. S., \& Slate, J. R. (2008). 'Teachers who left the teaching profession: A qualitative understanding,' The Qualitative Report, 13(1), 1-11.

Guardina, C. A., \& Fullerton, E. (2010). 'Changing behaviors by changing the classroom environment,' Teaching Exceptional Children, 42(6), 8-13.

Gutierrez, F. C., \& Shoemaker, D. J. (2008). 'Self-reported delinquency of high school students in Metro Manila: Gender and social class,' Youth and Society, 40(1), 55-85.

Hawkins, J. D., Catalano, R. S., Kosterman, R., Abbott, R., \& Hill, K. G. (1999). 'Preventing adolescent health risk behaviors by strengthening protection during childhood,' Archives of Pediatrics and Adolescent Medicine, 153, 226-234.

Hawkins, J. D. Kosterman, R., Catalano, R. Hill, K. G., \& Abbott, R. (2005). 'Promoting positif adult functioning through social development intervention in childhood: Long term effect from the Seattle Social Development Project,'Archives of Pediatric and Adolescent Medicine, 159, 25-31.

Henly, M. (2010) Classroom management: A proactive approach, Upper Saddle River, NJ: Pearson.

Kellam, S. G., Brown, C. H., Poduska, J. M., Ialongo, N. S., Wang, W., \& Toyinbo, P. (2008). 'Effects of a universal classroom behavior management program in first and second grades on young adult behavior, psychiatric, and social outcomes,' Drug and Alcohol Dependence, 95S, S5-S28.

Kellam, S. G., Mackenzie, A.C., Poduska, J. M., Wang, W., Petras, H., \& Wilcox, H. C. (20011). 'The Good Behavior Game and the future of prevention and treatment,' Addiction Science \& Clinical Practice, July, 73-84.

Kerr, M. M. \& Nelson, C. M. (2010) Strategies for addressing behavior problems in the classroom, Upper Saddle River, NJ: Pearson.

Kohn,A. (2006) Beyond discipline: From compliance to community, Alexandria, VA: Association for Supervision and Curriculum Development.

Kokkinos, C. (2007). 'Job stressors, personality and burnout in primary school teachers,' British Journal of Educational Psychology, 77, 229-243. 
Kunter, M., Baumert, J., \& Koller, P. (2007). 'Effective classroom management and the development of subject-related interest,' Learning and Instruction, 17, 494-509.

Leflot, G., van Lier, A. C., Onghena, P., \& Colpin, H. (2010). 'The role of teacher behavior management in the development of disruptive behaviors: An intervention study with the Good Behavior Game,' Journal of Abnormal Child Psychology, 38(6), 869-882.

Loeber, R., Farrington, D.P., Stouthamer-Loeber, M., Moffitt, T.E., \& Caspi, A. (1998). 'The development of male offending: Key findings from the first decade of Pittsburg youth study,' Studies of Crime and Prevention, 7, 1-31.

Madsen, C. H., Becker, W. C. \& Thomas, D. R. (2001). 'Rules, praise, and ignoring: Elements of elementary classroom control,' Journal of Direct Instruction, 1(1), 11-25.

Maguire, M. Ball, S., \& Braun, A. (2010). 'Behavior, classroom management and student control. Enacting policy in English secondary school,' International Studies in Sociology of Education, 20(2), 153-170.

Marzano, R., \& Marzano, J. S. (2003). 'The key to classroom management,' Educational Leadership, 61(1), 6-13.

Meister, D. G., \& Melnick, S. A. (2003). 'National new teacher study: Beginning teachers' concerns,' Action in Teacher Education, 24(4), 87-94.

Morrison, G., Anthony, S., Storino, M., \& Dillon, C. (2001). 'An examination of the disciplinary histories and the individual and educational characteristics of students who participate in an in-school suspension program,' Education and Treatment of Children, 24, 276-293.

Patterson, G., Reid, J., \& Dishion, T. (1992) Antisocial boys: A social interactional approach (Vol. 4), Eugene, OR: Castalia Publishing.

Pierce, E. W., Ewing, L. J., \& Campbell, S. B. (1999). 'Diagnostic status and symptomatic behavior of hard-to-manage preschool children in middle childhood and early adolescence,' Journal of Clinical Child Psychology, $28,44-57$.

Pisacreta, J., Tincani, M., Connell, J. E., \& Axelrod, S. (2011). 'Increasing teachers' use of 1:1 praise to behavior correction ratio to decrease student disruption in general education classrooms,' Behavioral Interventions, 26, 243-260.

Raby, R. (2010) 'The intraccies of power relations in discourses of secondary school discipline strategies' In Z. Millei, T.G. Griffiths \& R.J. Parkes (Eds.), Re-theorizing discipline in education: Problems, politics and possibilities, New York: Peter Lang Publishing Inc. 
Rinke, W. M., \& Herman, K. C. (2002). 'Creating school environment that deter antisocial behaviors in youth,' Psychology in the Schools, 39(5), 549-559.

Reinke, W. M., Stormont, M, Herman, K. C., Puri, R., \& Goel, N. (2011). 'Supporting children's mental health in school: Teacher perceptions of needs, roles, and barriers,' School Psychology Quarterly, 26, 1-13.

Rosnani Hashim. (2004) 'Education dualism in Malaysia: Implications for theory and practice', Kuala Lumpur: The Other Press.

Scott, S., Spender, Q., Doolan, M., Jacobs, B., \& Aspland, H. (2001). 'Multicenter controlled trial of parenting groups for child antisocial behavior in clinical practice,' British Medical Journal, 323, 1-5.

Slee, R. (1995) 'Changing theories and practices', London: The Falmer Press.

Smith, D. L. \& Smith, B. J. (2006). 'Perceptions of violence: The views of teachers who left urban schools,' The High School Journal, 89, 34-42.

Soodak, L.C. (2003). 'Classroom management in inclusive settings,' Theory into Practice, 42(4), 327-333.

Sullivan, A.M., Johnson, B., Owens, L., \& Conway, R. (2014). 'Punish or engage them? Teachers' views of unproductive student behaviors in the classroom,' Australian Journal of Teacher Education, 9(6), 43-57.

Sun, R. C. F. \& Shek, D. T. L. (2012). 'Student classroom misbehavior: An exploratory study based on teachers' perceptions,' The Scientific World Journal, 2012, 1-7.

Sutton, R., \& Wheatley, K. (2003). 'Teachers' emotions and teaching: A review of the literature and directions for future research,'Educational Psychology Review, 15, 327-358.

Stearns, E., \& Glennie, E. (2006). 'When and why drop out leave school,' Youth and Society, 38, 29-57.

Stoughton, E. H. (2007). “"How will I get them to behave?" Pre-service teacher reflects on classroom management,' Teacher and Teacher Education, 23, 1024-1037.

Thomas, Bierman, Powers, \& The Conduct Problems Prevention Research Group. (2011). 'The influence of classroom aggression and classroom climate on aggressive-disruptive behavior,' Child Development, 82(3), 751-757.

Thompson, B. (2009). 'Disruptive behaviors in Barbadian Classroom: Implication for universal secondary education in the Caribbean,' Journal of Eastern Caribbean Studies, 34(3), 39-58.

Travers, C. (2001) ‘Stress in teaching', In J. Dunham (ed.) Stress in the workplace: past, present and future, London: Whurr. 
Wakschlag, L., Leventhal, B., Briggs-Gowen, M., Danis, B., Keenan, K., \& Hill, C. (2005). 'Defining the 'disruptive' in preschool behavior: What diagnostic observation can teach us,' Clinical Child and Family Psychology Review, 8, 183-201.

Walker, H. M., Ramsey, E., \& Gresham, F. (2004) Antisocial behavior in school: Evidence-based practices, Thomson Wadsworth Publisher.

Wan Mazwati Wan Yusoff. (2012). 'Impact of Prophet Muhammad Motivation Techniques on Students' Performance,' The Procedia-Social and Behavioral, 69, 1700-1708.

Wan Mazwati Wan Yusoff \& Asyraff Hafdzan Abdullah. (2015).

'Evaluation of Prophet Muhammad's Techniques in Managing Misbehaviors: Application in Primary School Classrooms,' Journal of Educational and Social Research, 5(1), 185-194.

Way, S. M. (2011). 'School discipline and disruptive classroom behavior: The moderating effects of student perceptions,' The Sociological Quarterly, 52, 346-375.

Webster-Stratton, C. \& Reid, M. J. (2004). 'Strengthening social and emotional competence in young children-the foundation in early school readiness and success: Incredible years classroom social skills and problem solving curriculum,' Journal of Infant and Young Children, 17, 96-113.

Webster-Stratton, C. \& Hammond, M. (1997). 'Treating children with early-onset conduct problems: A comparison of child and parent training interventions,' Journal of Consulting and Clinical Psychology, 65, 93-109.

Wheeler, J. J. \& Richey, D. D. (2010) Behavior management: Principles and practices of positive behavior supports $\left(2^{\text {nd }}\right.$ edn.), Upper Saddle NJ: Pearson.

Yahyazadeh Jeloudar \& Aida Suraya Md Yunus, (2011). 'Teacher social intelligence and classroom discipline strategies,' International Journal of Psychological Studies, 3(2), 149-156.

Zyngier, D. (2007). 'Listening to teachers-listening to students: Substantive conversations about resistance, empowerment and engagement,' Teachers and Teaching: Theory and Practice, 13(4), 327-347. 